\title{
Community Women Intervention in haor Floodplain: A Case of Women-Led Cage Aquaculture from Kishoreganj haor Areas of Bangladesh
}

\author{
A. K. M. Nowsad Alam ${ }^{1}$, Shahidul Islam Bhuiya ${ }^{1}$, Fozlul Kabeer ${ }^{1}$, Al-Shahriar ${ }^{1, *}$, Mohammad Nuruz- \\ zaman $^{2}$ \\ ${ }^{1}$ Department of Fisheries Technology, Bangladesh Agricultural University, Mymensingh 2202, Bangladesh. \\ ${ }^{2}$ Krishi Gobeshona Foundation (KGF), A/C Building (3rd floor), BARC campus, Farmgate, Dhaka-1215, Bangladesh.
}

\begin{abstract}
How to cite this paper: A. K. M. Nowsad Alam, Shahidul Islam Bhuiya, Fozlul Kabeer, Al-Shahriar, Mohammad Nuruzzaman. (2020) Community Women Intervention in haor Floodplain: A Case of Women-Led Cage Aquaculture from Kishoreganj haor Areas of Bangladesh. International Journal of the Science of Food and Agriculture, 4(4), 492-501.

DOI: 10.26855/ijfsa.2020.12.018
\end{abstract}

Received: October 26, 2020

Accepted: November 24, 2020

Published: December 30, 2020

*Corresponding author: Al-Shahriar, Department of Fisheries Technology, Bangladesh Agricultural University, Mymensingh 2202, Bangladesh. Email: alshahriar12@gmail.com

\begin{abstract}
Haors are natural low-lying watersheds inundated for 5-6 months by flood waters across the northeastern part of Bangladesh. Fishermen in haors are engaged in fishing, while the fisherwomen are involved in wet fish trading, fish drying, net mending, crafting traps and gears but never engage in aquaculture. This paper discusses the community participations in women-led cage aquaculture as an alternative livelihood for haor areas. The interventions included formation of women groups from two distinct fishing communities-ethnic fisherwomen (EFW) and mainstream poor women (MPW) groups, where 10 cages of tilapia monoculture was demonstrated to each group with hands-on training and inputs. A 4-month cage culture study, having a cage size of $27 \mathrm{~m}^{3}$, obtained 15.56 $\mathrm{kg} \cdot \mathrm{m}^{3-1}$ and $14.52 \mathrm{~kg} \cdot \mathrm{m}^{3-1}$ respectively in EFW and MPW with FCR values of 1.11 and 1.21 in that order ( $>0.05)$. The produce of EFW group was sold by themselves in both wholesale and retail markets and accordingly, profit margins were higher by $9.02 \%$ compared to MPW group. The results were encouraging towards adopting haor aquaculture as viable alternative livelihood option by fisherwomen across the haor floodplain.
\end{abstract}

\section{Keywords}

Haor, Fisher women, Tilapia cage culture, Alternative livelihood

\section{Introduction}

Bangladesh is composed of mainly the great combined delta and floodplains crisscrossed by numerous rivers and their tributaries. Bangladesh alone has over 3.9 million ha of open water areas, of which 2.71 million ha is floodplain [1]. Most of the inland open water bodies including extensive floodplains are still left only for capturing the natural stocks and remain un-utilized for aquaculture. Wise use of the potential vast floodplain waters by culturing fish could assist fulfilling the demand of national protein intake. Cage culture could be the most suitable aquaculture technique to optimally utilize the productivity of floodplains in monsoon and rainy season [2]. Cage culture has been successfully practiced by many South Asian countries like China, Vietnam, Thailand, and Kampuchea for boosting their aquaculture production [3]. Average fish production in the floodplains in Bangladesh is particularly low, only $283 \mathrm{~kg} / \mathrm{ha}$ [1], which can easily be increased to 2 to $5 \mathrm{MT}$ /ha by community-based operation of cage culture of fast growing popular species [4].

In Bangladesh, more than 17 million people including about 1.4 million women depend on fisheries sector for their 
livelihoods through fishing, farming, fish handling, and processing [5]. Fishing could be a fulltime occupation of men; however, the involvement of women is also significant. Nevertheless, full time engagement of women in fisheries is no longer a rare scenario. They are directly or indirectly engaged in activities like making fishing nets, gears, repair and maintenance of the gears, sorting of fingerlings (especially in coastal areas), fish processing, transportation, marketing etc. Yet, most women in fisheries lack access to physical and capital resources, to decision-making and leadership positions, to training and formal education. Access to these critical resources and services would improve the efficiency, profitability and sustainability of their activities. Women should be equal partners and productive participants in fisheries activities that will improve their own and their families nutritional and living standards. They should be given the opportunity to acquire appropriate technologies that will enable them to contribute effectively to sustained fisheries development and growth [6]. It is therefore essential to increase women's participation and decision-making in fisheries development policies. Women and gender programs in fisheries cannot be left to mainstream gender and social welfare agencies as these seldom give priority to fisheries. Fish sectors must develop their own gender approaches. In addition, within the fish sectors, family and community-based approaches rather than women's activities are more likely to succeed and last [7]. Women play a crucial role in aquaculture production in many Asian countries [8]. For example, in Cambodia, higher yields are obtained from fish ponds managed mainly by women [9]. In Thailand and China, they often bear sole responsibility of farm and aquaculture production because of male migration to cities. Small-scale aquaculture development is increasingly considered as a means by which the livelihoods of the poor, including women, could be improved [10-11]. Women's participation in aquaculture was recognized by many researchers largely from an instrumental perspective. In rural Asia, women are excluded from participation in community-level management of natural and other resources, from relations with external agencies and from political representation. Exclusion of women from management functions refrain from the strengthening of community's capabilities. The role of women in fisheries encompasses social and economic tasks both within and outside the family [12].

Women spend a major part of the day doing household chores. Some women are simultaneously involved in fisheries-related work, along with other income-generating activities. Women's involvement in income-generating activities to supplement the family income enables their male counterparts to work elsewhere [13]. It is generally accepted that women participate actively in the rural economy due to their social and economic roles. According to Ani [14], women are the backbone of agriculture labour force producing $40 \%$ of the gross domestic product (GDP) and over $50 \%$ of food in developing nations. Sultana et al. [12] describe the development of a women-led beel (seasonal water body) management committee in Goakhola-Hatiara, Bangladesh, from its inception as a women-only group formed by a women's NGO, Banchte Shekha, in 1997 to more inclusive and women-led management committee in 1999. In the coastal areas many women are engaged in collecting seed, transportation and marketing of the fingerlings [15]. Marketing of the products can also be an important area for the involvement of women in greater number. Bhaumik et al. [16] identified the socio-economic problems as perceived by rural women-folk which impeded their participation in various inland fisheries activities in West Bengal, India. Women in Asia, especially those from depressed fisheries households, participate actively in many fisheries activities, including aquaculture and they have huge contributions towards the sustainable fisheries [17]. Felsing et al. [18] analyses the role of women in the aquaculture sector in Southeast Asia. Aquaculture is becoming very important in the region but the role of women has often been adversely affected. Gopalakrishnan [19] describes women in India are involved in various facets of shrimp farming, including pond construction, seed collection, collection of feed materials and preparation of feeds, pond maintenance and post-harvest handling. Women in Cantho City are profitably involved in fish nursing activities [20]. Nam et al. [9] studied women's involvement in small-scale aquaculture development in Cambodia. Sultan [21] examines the role played by women in fisheries (capture fisheries; transportation, processing and marketing; nets and gears; and ornamental fisheries) in rural environments in India and found encouraged to participate. Women involvement in the Asian countries is rather intense in post-harvest fisheries sector. The rural economy in Nigeria is dominated by women through their participation in crop and animal production, marketing as well as processing [22] Women have important roles as producers of food, managers of resources and as income earners [23]. However, to ensure sustainability in homestead fish production and to provide substantial income for women, there may be need to develop an extension system that is gender specific and is tailored towards women. This can be achieved if the required level of women's involvement in aquaculture activities is ensured. The situation is rapidly changing and in recent years emphasis has been laid on providing opportunities for women participation in all sectors of fisheries [8]. Precise diminutive research has been conducted in Bangladesh to examine the nature and extent of the involvement of women in the fisheries sector and the impact of such involvement on women's status and gender relations in the household and in the community aspect [24]. Little research has gone into the question of how fisheries affects the status of women and gender relations in the household and the community and how in turn these relationships influence the effectiveness of aquaculture in improving livelihoods and addressing poverty. The present study focuses on community-based women intervention in fisheries and aimed to develop strategies to improve women livelihood goals through aquaculture development.

It will also answer whether aquaculture development play a role in women's empowerment and social advancement. 
This study was conducted with an attempt to carry-out the feasibility of tilapia (Oreochromis niloticus) culture in cages in the haor areas with the functional involvement of poor women high-lighting both technical and economic viability in Bangladesh.

\subsection{Hypothesis:}

It was hypothesized that monosex tilapia culture in cages in haor areas could be a suitable and cost-effective sustainable aquaculture technique to enhance the livelihood of women fishers.

\section{Materials and Methods}

\subsection{Site Selection}

Sutar para Haor in Sutarpara Union under Karimganj Upazila of Kishoreganj district is potentially important for seasonal catch of hoar fishery. Huge numbers of poor fisher families living in adjacent villages earn their livelihood from this haor. Fish catch has seriously declined nowadays due to over-fishing, killing of gravid females, destroying stock by dewatering of the pits at dry season and/or by use of agricultural pesticides. The experiment was conducted in exclusively open haor water located at the Sutarpara union parishad (connected with Ujan Dhanu Jalmahal), Karimganj Upazilla of Kishoreganj in Bangladesh $\left(24^{0} 27^{\prime} 40.97^{\prime \prime} \mathrm{N} ; 90^{0} 58^{\prime} 16.61^{\prime \prime} \mathrm{W}\right.$, Figure 1). This region was selected because of inhabitance of resource poor ethnic and mainstream poor women fishers, the suitable geographical settings for cage aquaculture with available water resources round the year (e.g. haor connected river that flows near by the community), development challenge (e.g. lack of knowledge), preference for tilapia culture technique development.

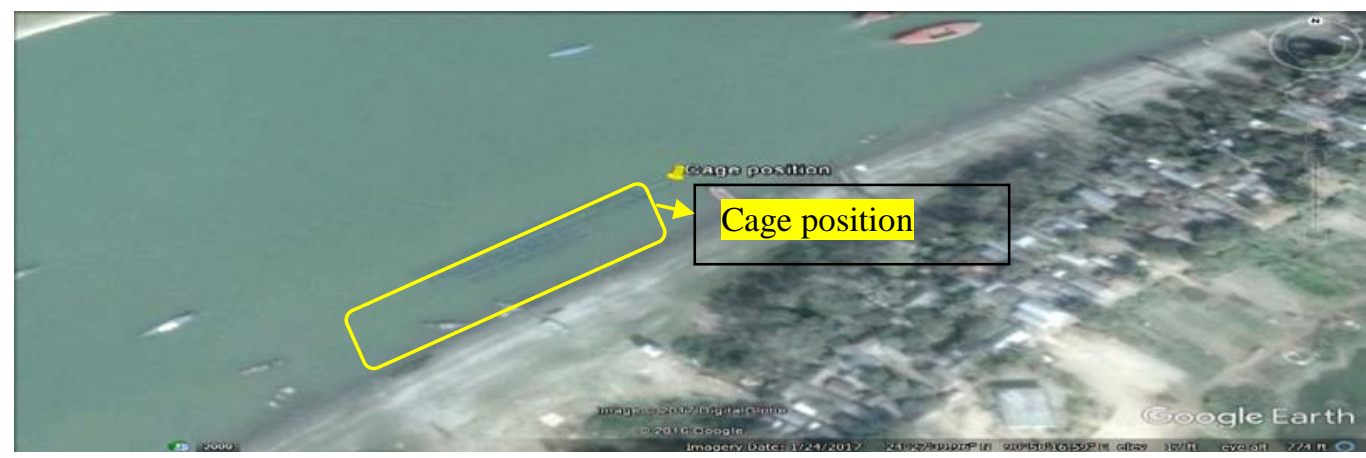

Figure 1. Research site (picture taken from Google Earth).

\subsection{Community Selection and Formation of Groups}

Out of 40 resource poor women fishers' households of Ujan dhanu Nadi Matshayajibi Samabaya Samiti (UNMJSS) involved in community based organization only ten (10) households were selected for conducting the trials for 4 months. Out of 51 resources, poor women fishers' households of Sutarpara Matshayajibi Samabaya Samiti involved in community based organization only ten (10) households were selected for conducting the trials for 4 months. As these community have already selected for "Production enhancement of aquaculture through innovative technologies in cage culture system in haor areas of Karimganj, Kishoreganj” funded by KGF (Krishi Gobeshona Foundation). Research was directly implemented by the women targeting to enrich them through hands-on training in different management issues (e.g. fingerling release, feeding, applying medicine, sampling and marketing) in haor areas. The interventions include formation of two women groups (Ujan dhanu Nadi Matshaya Jibi Somobaya Samititi (UNMJSS) and Chongnoagaon Matsaya Samabaya Samiti (CMSS) from two distinct fishing communities of Sutarpara Union-ethnic fisherwomen (EFW) and mainstream poor women (MPW) groups.

\subsection{Cage Management and Training}

The women fishers had very less knowledge on aquaculture. The training delivered to women fishers started from basic to improved technologies and optimum resource management. To test the feasibility of species of fish culture (3 or 4 stocking densities) were used to find out the best stocking density in terms of both growth performance and profit.

\subsection{Cage installation, Stocking Management and Feeding Strategies}

All the cages were rectangular in shape having submerged $27 \mathrm{~m}^{3}$ volume. In constructing cages basic design used in Dakatia river cage culture system [25] was followed. Twenty cages were constructed for two groups, while each of the 20 fisherwomen from 2 groups operated one cage. Size of each cage was $6 \mathrm{~m}$ x $3 \mathrm{~m}$ dimension. Cage frames were constructed by $2.54 \mathrm{~cm}$ diameter GI pipe. Cage height was maintained based on depth of water, preferably $\geq 2 \mathrm{~m}$. The cage 
frame was arranged in series keeping $45 \mathrm{~cm}$ gap between the two to accommodate exhausted barrels as float. The frames were set by connecting rods with claps in each head. Cages were arranged in several rows since water sharing for navigation was minimum in the haor. The cage frames were attached with one another in a series supported to float by exhausted 200 liter (wt. $12 \mathrm{~kg}$ ) plastic barrels. The whole structure was hardened by binding with bamboo.

Monosex tilapia $(7 \pm 0.2 \mathrm{~cm} / 30 \pm 2 \mathrm{~g})$ was stocked randomly in each cage at same stocking density of 35 indiv. $\mathrm{m}^{3-1}$. Proper care was taken in transporting, holding and handling fingerlings to avoid heavy mortality. Fingerlings were needed to keep cool and in clean fresh water. The water temperature in the transport container and the cage was the same. Fingerlings were not touched more than is absolutely necessary. Once in the cage, dead fish found floating removed daily and recorded. The rule of thumb was that for every dead fish found floating, two dead fish sank. Thus, three times the number of fish found floating dead during the first week were stocking mortalities and replaced with new fingerlings. Mortalities occurring later were noted for the purposes of calculating the feeding rate but not replaced, as replacement would mostly increase variability in the harvested population.

Fish were fed daily twice in the morning (8:00-10:00 am) and afternoon (3:30-5:30 pm). Fish in cages was fed with a brand floating crumbled feed containing approximately (25\%-32\% crude protein). The amount of feed was adjusted fortnightly. Fish were fed at a declining rate (ranging from $10 \%$ down to $2 \%$ of estimated average body weight, administered at satiation level twice daily based on the fortnightly average weight of a sample of at least $5 \%$ of original stock from each treatment.

\subsection{Fingerling Collection}

Fish fingerlings were collected from a commercial fish hatchery "Sharnalata Agro Fisheries Ltd., Mymensingh, Bangladesh”, about $100 \mathrm{~km}$ west from the field research site and only $15 \mathrm{~km}$ west from the lab research site.

\subsection{Cage Setting and Fish Shifting}

Net materials for construction of cages were purchased from a net factory of Chandpur. Four-side walls of the set cage were fabricated with nylon net of knotted webbing. The mesh size of the net was $2 \mathrm{~cm}$. A finer meshed net of 0.5 meter height was fixed to the upper inner side of the cages to protect the floating feed pellet escaping out. A larger meshed net, for example $5.0 \mathrm{~cm}$, was used to cover the cages on top to protect fish from birds. After setting the cages in water, the nets were exhausted for about 15 days to lose the roughness of inner side to avoid physical injury to the fingerlings. Every after 1 month, both inner and outer sides of the nets were rubbed by coarse materials (old net, monofilament scrap, brush, etc.) to remove algae, clay and debris to keep the water movement inside the cages easy. Fish were sampled fortnightly and treated with $\mathrm{KMnO}_{4}$ and $\mathrm{NaCl}$ at the dose of $5 \mathrm{mg} / \mathrm{l}$ and $10 \mathrm{mg} / \mathrm{l}$ simultaneously for 1 minute bath to prevent any infections.

\subsection{Management Monitoring}

Technical data were collected and the activities recorded in terms of labor inputs, cage maintenance, nursing and cost and sale of fingerling and fish. After completion of the experiment, total fish were weighed from each cage for final biomass assessment. In addition, information on socio-economic factors (e.g. education level, land resources, income sources) were collected at the beginning of the research. Participation of household women fishers was monitored by activity record chart. Different growth parameters were calculated by the following formulas.

(1) Biomass gain (BG) $\left(\mathrm{kg} \mathrm{cage}^{-1}\right)=$ Final biomass (FB) $\left(\mathrm{kg} \mathrm{cage}^{-1}\right)$ - initial biomass (IB) $\left(\mathrm{kg} \mathrm{cage}^{-1}\right)$; (2) Feed conversion ratio $(\mathrm{FCR})=$ Total dry weight of feed offered $\left(\mathrm{kg} \mathrm{cage}^{-1}\right) / \mathrm{BG}\left(\mathrm{kg} \mathrm{cage}^{-1}\right)$ during the experimental period.

Profit was calculated considering the total cost (fixed cost and depreciation cost) and variable operational cost that includes the cost of feed, fingerling cost, chemical \& medicine and labor charges and miscellaneous cost. The sale value of advanced fish produced in different treatments was considered as BDT kg-1 [1 US\$ = BDT 80] according to the prevailing rate followed by most of fish producers. The following calculations were used in economic viability analysis.

Table 1. Calculations for parameters used

\begin{tabular}{ccc}
\hline Sl no. & Parameters & Calculations \\
\hline 1. & Fixed cost (FC) & Cost of cage construction +depreciation \\
2. & Variable cost (VC) & Cost of feed + fry + labor + medicine + miscellaneous \\
3. & Total cost (TC) & FC +VC \\
4. & Gross revenue (GR) & Total biomass kg $\times$ sale value kg ${ }^{-1}$ \\
5. & Gross margin (GM) & GR - TC \\
6. & Net revenue (NR) & GR / TC \\
7. & Revenue cost ratio (BCR) & NR $\times 100) / T C$ \\
8. & Profitability (\%) \\
\hline
\end{tabular}




\subsection{Fish Sell}

The produce of EFW group were sold by the fisherwomen themselves in both wholesale and retail markets, while MPW took assistance of their husbands in selling fish only in wholesale.

\subsection{Water Parameters}

Water temperature, $\mathrm{pH}$ (CRISON Model 507; Barcelona, Spain), dissolved oxygen (HACH test kit, Model-OX-2P, USA) ammonia (HACH test kit, USA), were measured daily inside the cages. The wave length (Model-621B MIR laser-wavelength, USA), wave crest (Model-DTS 2079, USA) and water current (Model WL 16 Water Level Logger, USA) were measured daily by setting these digital instruments.

\subsection{Analysis of the Outcomes}

Statistical analysis was carried out using SPSS (version-22) according to the method of Steel and Torrie [26] (SPSS, Inc., Chicago, Illinos, USA). The efficiency of production of tilapia was compared in terms of $\mathrm{kg}$. cage ${ }^{-1}$. Analysis of variance, ANOVA and F-test were used to test the differences in fish in the study areas. Before performing ANOVA a normality test was performed on main dependent variable to verify whether the data were normally distributed or not. A significance level $(\mathrm{p}<0.05)$ was used in all tests.

\section{Results}

\subsection{Fish Production}

Growth performance of tilapia fingerlings in 20 cages was found to be technically successful in haor areas and presented (Table 2). A significant difference in growth performance parameters was obtained between the two groups (Figure 2). The mean value of biomass gain $\left(\mathrm{kg} \mathrm{cage}^{-1}\right)$ was significantly increased in EFW group than MPW group where biomass gain per cage was 420 and $392 \mathrm{~kg} \mathrm{cage}^{-1}$ respectively. Conversely, the FCR in EFW group was 1.11 and in MPW group was 1.21, which was significantly lower than MPW group. No significant difference was observed in the survival rate of tilapia between EFW and MPW groups.

Table 2. Yield parameters (mean \pm SD) of tilapia in two research sites

\begin{tabular}{cccc}
\hline Parameters & EFW $^{*}$ & MPW $^{*}$ & sig. \\
\hline Initial average body weight (IABW) (g) & $30.12 \pm 2.43$ & $30.12 \pm 2.43$ & - \\
Stocking density (ind. $\left.\mathrm{m}^{-3}\right)$ & 800 & 800 & - \\
Biomass gain (kg. cage $\left.^{-1}\right)$ & $15.56 \pm 1.77^{\mathrm{a}}$ & $14.52 \pm 1.91^{\mathrm{a}}$ & 0.444 \\
FCR $^{*}$ & $1.11 \pm 0.02^{\mathrm{b}}$ & $1.21 \pm 0.03^{\mathrm{a}}$ & 0.000 \\
Survival (\%) $^{\mathrm{a}}$ & $92 \%^{\mathrm{a}}$ & $90 \%^{\mathrm{a}}$ & 0.143 \\
\hline
\end{tabular}

*Mean values with different superscripts in the same row are significantly different $(\mathrm{p}<0.05)$ based on Duncans’ multiple range test. *Ethnic fisherwomen (EFW), Mainstream poor women (MPW) groups, Food conversion ratio (FCR).

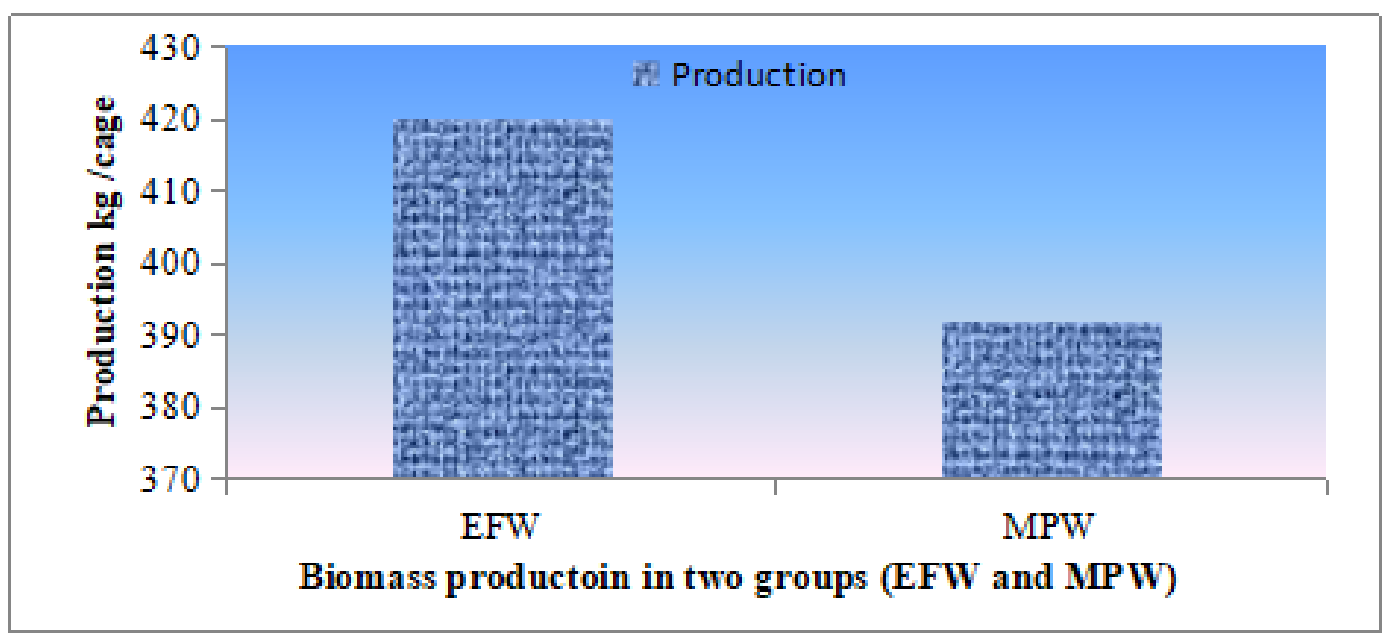

Figure 2. Comparative biomass production (kg/cage) in two groups (EFP and MPW). 


\subsection{Economic Performance}

Viable economic approaches usually rely on the lower value of required total cost (TC) than the gross margin (GM). The difference of production cost of tilapia in EFW and MPW groups was minimal and not significant. Feed cost and fingerling cost accounted for over $90 \%$ of the total variable cost. The variable cost was not significantly differed between two groups. A selling price for EFW was US\$ 1.5 and for MPW was US\$ 1 and no significant difference was found. Taking a closer look at the output economic parameter of gross margin, net profit margin differed significantly $(\mathrm{p}<0.05)$. In addition to that the variable cost was almost leveled off over the research. The gross revenue was US\$ 630 for the EFW group which was significantly higher than the MPW group (US\$ 578.20).

In EFW group, a 9\% of the produce was sold on-farm on the spot, while $65 \%$ was sold in the local retail markets and rest $26 \%$ was sold in local auction center/wholesale market for distribution all over the country through traders locally called paikers (Table 4). In contrast, in MPW group, 15\% of produce was sold on-farm, $24 \%$ was sold in the local retail markets and rest $61 \%$ was sold in wholesale market. The individual unit price $\mathrm{kg}^{-1}$ of fish ranges from US\$ 1.48 and 1.5 over the period of the trials in group MPW and EFW respectively. Table 3 represents the participation of household members in different cage aquaculture activities over the crop cycles. Here it is clear that the women or girl participation was noticeable.

Table 3. Household participations

\begin{tabular}{|c|c|c|c|c|}
\hline \multirow{2}{*}{ Village } & \multirow[t]{2}{*}{ Activities } & \multicolumn{2}{|c|}{ Household members } & \multirow[t]{2}{*}{ Remarks } \\
\hline & & Men/boys & Women/girls & \\
\hline \multirow[t]{5}{*}{ UNMJSS $^{*}(\mathrm{n}=10)$} & cage installation & $10(100)$ & - & \multirow{10}{*}{$\begin{array}{l}\text { The cage aquaculture activ- } \\
\text { ities performed by the } \\
\text { household members varied } \\
\text { between the two groups. }\end{array}$} \\
\hline & collection of fingerlings & $10(100)$ & & \\
\hline & Feeding & $3(30)$ & $7(70)$ & \\
\hline & Sampling & $5(50)$ & $5(50)$ & \\
\hline & transportation and selling & - & $10(100)$ & \\
\hline \multirow[t]{5}{*}{ CMSS $^{*}(n=10)$} & cage installation & $10(100)$ & - & \\
\hline & collection of fingerlings & $10(100)$ & & \\
\hline & Feeding & $6(60)$ & $4(40)$ & \\
\hline & Sampling & $7(100)$ & $3(30)$ & \\
\hline & transportation and selling & $7(100)$ & $3(30)$ & \\
\hline
\end{tabular}

*Ujan dhanu Nadi Matshaya Jibi Somobaya Samititi (UNMJSS), Chongnoagaon Matsaya Samabaya Samiti (CMSS).

Table 4. Marketing of tilapia

\begin{tabular}{cccc}
\hline \multirow{2}{*}{ Marketing patterns } & \multicolumn{2}{c}{ Groups } & Comments \\
\cline { 2 - 3 } & UNMJSS (EFW) (\%) & CMSS (MPW) (\%) & The marketing of aqua produce \\
On-farm selling & 9 & 15 & 24 \\
metainly done by the UNMSS (EFW) \\
group while the other group CMSS \\
Wholesale (local arot) & 65 & 61 & (UNMSS) took assistance from their \\
husbands.
\end{tabular}

*Ujan dhanu Nadi Matshaya Jibi Somobaya Samititi (UNMJSS), Chongnoagaon Matsaya Samabaya Samiti (CMSS), Ethnic fisherwomen (EFW), Mainstream poor women (MPW) groups.

\subsection{Economic Returns towards EFW and MPW groups}

Over $90 \%$ of engaged community fishers in tilapia production activities are now able to carry out the associated activities at monsoon through applying the achieved technical knowledge from the given need oriented training during the project tenure. The line graph (Figure 3) demonstrates the comparative economic progress in terms of gross revenue gathered by them. Considering their base line income state, the trend of income in EFW and MPW groups were upward and increased at $43.80 \%$ and $34.78 \%$, respectively (Table 5). Previous incomes of both the groups were not sufficient to buy their daily food consumption and other subsistence activities but after joining the cage aquaculture, their average income was increased and now they are capable enough to meet their family needs. 


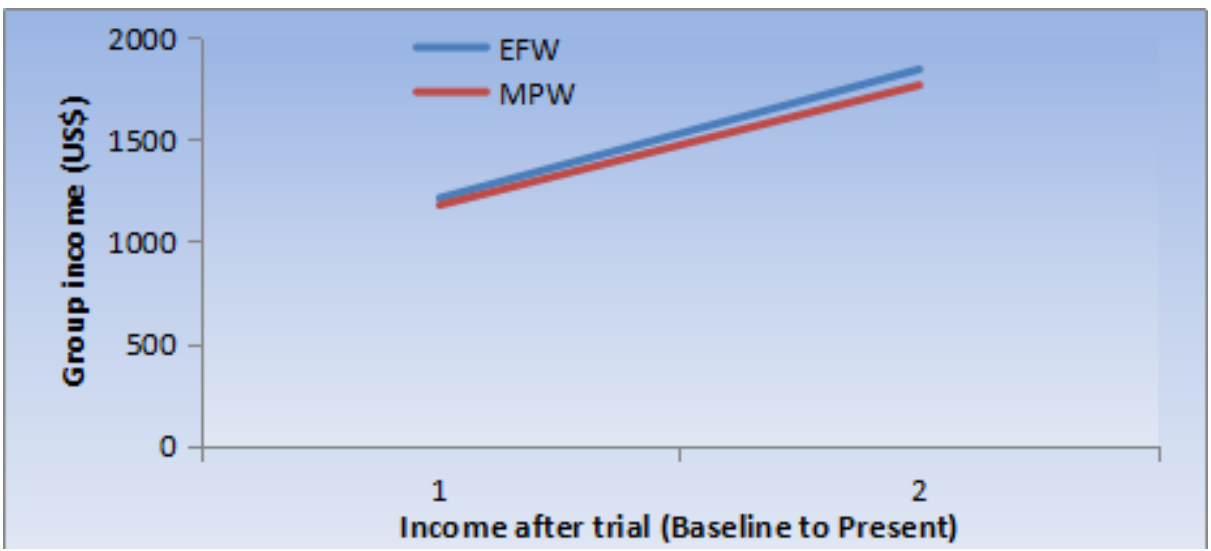

Figure 3. Comparison of income from baseline to after trial between two groups.

Table 5. Comparative cost benefit analysis (US\$) of tilapia cage aquaculture for 4 months trial in EFW and MPW groups

\begin{tabular}{|c|c|c|c|c|}
\hline \multicolumn{2}{|c|}{ Particulars } & \multirow{2}{*}{$\frac{\text { EFW }^{*}}{21.25}$} & \multirow{2}{*}{$\begin{array}{c}\text { MPW }^{*} \\
21.25\end{array}$} & \multirow[t]{2}{*}{ Sig. } \\
\hline & Cage construction cost & & & \\
\hline Fixeu cost & Depreciation cost (cage) & 5.5 & 5.5 & \\
\hline Sub total & & 26.75 & 26.75 & 0.000 \\
\hline \multirow{5}{*}{ Variable cost } & Feed cost crop $^{-1}$ & $291.25 \pm 22.51^{\mathrm{a}}$ & $296.25 \pm 32.54^{\mathrm{a}}$ & 0.000 \\
\hline & Fingerling cost crop $^{-1}$ & $23.06^{\mathrm{a}}$ & $23.06^{\mathrm{a}}$ & 0.000 \\
\hline & 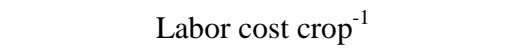 & 10.5 & 10.5 & \\
\hline & Medicine cost crop $^{-1}$ & 4 & 4 & \\
\hline & Miscellaneous cost crop $^{-1}$ & 4 & 4 & \\
\hline Sub-total of variable cost & & $327.31 \pm 33.36^{\mathrm{a}}$ & $332.31 \pm 49.54^{\mathrm{a}}$ & 0.000 \\
\hline Total cost (TC) crop $^{-1}$ & $\mathrm{TC}=\left(\mathrm{FC}^{*}+\mathrm{VC}^{*}\right)$ & $354.06 \pm 66.66^{\mathrm{a}}$ & $359.06 \pm 61.77^{\mathrm{a}}$ & 0.000 \\
\hline Gross revenue (GR) crop $^{-1}$ & $\mathrm{GR}=\left(\mathrm{kg}\right.$ of fish harvested* price $\left.\mathrm{kg}^{-1}\right)$ & $630 \pm 85.33^{\mathrm{a}}$ & $578.20 \pm 77.12^{b}$ & 0.002 \\
\hline Gross margin (GM) & $\mathrm{GM}=(\mathrm{GR}-\mathrm{VC})$ & $297.63 \pm 39.23^{b}$ & $250.63 \pm 25.01^{\mathrm{a}}$ & 0.000 \\
\hline Net profit (NP) crop $^{-1}$ & $\mathrm{NP}=(\mathrm{GR}-\mathrm{TC})$ & $275.94 \pm 44.29^{\mathrm{a}}$ & $219.14 \pm 35.16^{\mathrm{b}}$ & 0.000 \\
\hline Profit margin (\%) & & $43.80 \pm 4.92^{\mathrm{a}}$ & $34.78 \pm 7.14^{\mathrm{b}}$ & 0.000 \\
\hline
\end{tabular}

Mean values $( \pm \mathrm{SD})$ in the same row having the different superscripts are significantly different $(\mathrm{p}<0.05) .{ }^{*}$ Ethnic fisherwomen (EFW), Mainstream poor women (MPW) groups, Food conversion ratio (FCR), Variable cost (VC), Fixed cost (FC).

\section{Discussion}

\subsection{Technical Feasibility}

\subsubsection{Culture Environment Tools/Parameters}

The physico-chemical parameters of culture medium viz. temperature, wave length, wave crest, water current, dissolve oxygen, $\mathrm{pH}$ and ammonia found during the trial period were maintained by both the groups. The differences were not significant because all the physico-chemical parameters applied equally without any biasness in both the groups over the trial period. The water temperature measured for the whole trial period for both groups was $28.80^{\circ} \mathrm{C}$ to $31.40^{\circ} \mathrm{C}$ that was in the suitable range as almost parallel results were reported by Asaduzzaman [27] ranged between $26^{\circ} \mathrm{C}$ and $32.44^{\circ} \mathrm{C}$ in case of pond system. Here although the culture environment was not same but the recorded parameter was not differed significantly. The most vital parameter dissolve oxygen for both groups was in the range of 5.2 to 6.2 that were excellent for the culture of tilapia. The best dissolve oxygen was the effects of continuous water flow and wave length are the most important physical factors to upsurge the dissolve oxygen level in the haor waters. On the other hand, comparatively lower dissolve oxygen was recorded by Ahmed et al. [28] in pond system that was also fit for fish aquaculture.

Haor water $\mathrm{pH}$ varied in both the groups was 7.4 to 8.7 that was slightly higher than the findings of Wahab et al. [29] the higher range might be due to the cumulative effects of other physico-chemical parameters of haor waters. It is worth 
mentioning that these ranged were also suitable for the normal growth of the stocked fingerling. It was surprising that the ammonia content in the haor waters was just nil during the whole experimental period and it was unbelievable water quality in any aquaculture system in Bangladesh. Hence, it is expected for any aquaculture farming anywhere. However, as a whole, the water quality parameters found in both the research sites were non-toxic and in the range of favorable aquaculture standards [30]. In the present investigation, the cage culture area was too small in comparison to vast haor waters. The analysis of water quality suggests that cage aquaculture can be done safely without any harmful effect on the aquatic ecosystem. But the mean values of the parameters (e.g. water current, wave length and wave crest) not varied significantly for two sites. Result for dissolve oxygen ranged from 5.28-5.5 and that was in line with the findings of Banerjee [31] where the optimum dissolves oxygen level for successful aquaculture range from $5 \mathrm{mgl}^{-1}$ to $7 \mathrm{mgl}^{-1}$. The mean values of $\mathrm{pH}$ of this study comply with the findings of Swingle [32]. The wave length, wave crest and water current were also insignificant between two sites and the result matched with the findings of Moller [33].

\subsubsection{Growth Parameters}

Final biomass gain of tilapia operated by EFW was not significantly higher than MPW operated cage aquaculture venture. The mean values of FCR showed positive outcome of need based training offered by the said project. These results also described the fact that efficient utilization of diets can vary in different women groups because of proper management initiated by the EFW and MPW groups. In present research, the survival rates were not significantly differed due to received training and might be due to the physico-chemical factors of the culture medium namely higher dissolve oxygen and nil content of ammonia in the haor waters.

\subsubsection{Economic Parameters}

The rules of thumb, higher investment produces higher profit with the same unit of natural resources especially in high cost involved venture. But for small scale farming that prevails in community based cage aquaculture system should be profit oriented but investment capability also needs to be taken into account Kunda et al. [34]. Although the profit margin was slightly lower in MPW group but the profit margin were much higher in EFW group. The higher profitability observed by Osofero et al. [35] might be due to higher fish selling price at the culture area. The selling price or gross revenue data were not significantly $(p>0.05)$ higher in the EFW group than the MPW at the research sites as culture activities operated by the two different women groups which indicated that there are positive effects of training, skills given from the said project and attitude of social community.

\section{Conclusion}

It was revealed from this study that the Government or other agencies can improve and promote the participation of women in fisheries activities in a manner that is appropriate to the assessments of the different social and regional groups of women in the fisheries sub-sector. The present experiment proved that the women are capable enough to manage any adverse situation by their collective efforts. The women fishers have much higher capacity to manage the feeding and nursing activities in haor areas than women in land-based aquaculture system. Because they are more exposed and habituated with open water capture fishery activities like managing wind and water current in boats, sorting of wild catch, angling and therefore, their skill and confidence level were increased, in addition to adequate and repeated training. Present initiatives to improve the livelihoods of the poor in haor areas of Kishoreganj district through cage aquaculture brought about some changes which have affected the women positively in a number of ways e.g. increased participation of women in productive economic activities, increase household income, less vulnerability to social risks and increased food security of households. This created a new scope of fish trading that earns additional cash income for the family. Tilapia trading has been coming up as an increasing trend over the haor culture sites due to climbing demand of quality tilapia produced in cage aquaculture system. Most of the tilapia was sold from the on farm-site in the haor. For the sustainability of cage aquaculture, tilapia cage aquaculture system would be an excellent tool that can enhance income and improve livelihood of fishers' community. The key technical factor that influenced the success of tilapia production in cage aquaculture system was identified to be training and logistic supports, in order for the horizontal expansion of this technology. Tilapia culture in cage aquaculture system had been proved to be very simple and adoptable method that could be introduced in other parts of open water systems.

\section{Recommendations}

The following recommendations are suggested in order to enhance the participation of women in cage aquaculture:

- $\quad$ The women should be encouraged to participate in cooperative societies.

- There is a need to organize training on cage culture related activities (like fish feed formulation, rising of fingerlings and disease control) for women involved in homestead fish production.

- Women in the study area should be linked with micro-finance banks in order to have easy access to credit which can be used to increase their level of participation in fish production. 
- $\quad$ The men in the study area should be sensitized to free up women's time to enable them to spend more time for other non-household economic activities.

\section{Acknowledgements}

The authors gratefully acknowledge the financial and logistic supports provided by the Krishi Gobeshona Foundation (KGF) for carrying out the study. Cordial supports rendered by the project operators, shareholders and beneficiaries are highly acknowledged.

\section{Conflict of Interest}

The authors have no conflict of interests.

\section{References}

[1] Department of Fisheries (DoF). (2019). National Fish Week 2019 Compendium (in Bengali), Department of Fisheries, Ministry of Fisheries and Livestock, Bangladesh, p. 160.

[2] Department of Fisheries (DoF). (2017). Yearbook of fisheries statistics of Bangladesh 2016-17. Fisheries Resources Survey System (FRSS), Department of Fisheries, Bangladesh: Director General, Dhaka, Bangladesh, p. 129.

[3] ATA. (2010). American Tilapia Association. Www: American Tilapia Association.org.

[4] DoF (Department of Fisheries). (2010). A training Manual on Cage Culture, Dakatia Model, Department of Fisheries, Matsaya Bhaban, Dhaka, Bangladesh.

[5] BFTI. (2016). Bangladesh foreign trade institute, study on sector based need assessment of business promotion council-fisheries products. Kawran Bazar, Dhaka, pp 16. http://www.bfti.org.bd/pdf/Fishery.pdf.

[6] Ulrich, K. (2001). Fish distribution from coastal communities - market and credit issues. Workshop at the CARITAS auditorium, Chittagong, on Poverty Alleviation and Livelihood Security among the Coastal Fishing Communities, 27-28 March, 2001.

[7] Halim, S. and Ahmed, M. K. (2006). Women in fisheries in Bangladesh: Level of involvement and scope for enhancement. In: Choo PS, Hall SJ, Williams MJ (Editors.), Global Symposium on Gender and Fisheries, pp. 159-168. Seventh Asian Fisheries Forum, 1-2 December 2004, Penang, Malaysia. Penang: World Fish Center.

[8] FAO. (2017). Women's empowerment in aquaculture two case studies from Indonesia. ISBN 978-92-5-109859-2, p. 132.

[9] Joffre, O., Kura, Y., Pant, J., and So, N. (2010). Aquaculture for the poor in Cambodia. The WorldFish Center, Phnom Penh, Cambodia, p. 20.

[10] FAO. (2010). Enhancing the contribution of small-scale aquaculture to food security, poverty alleviation and socio-economic development. FAO fisheries and aquaculture proceedings, ISSN 2070-6103 FAO Expert Workshop 21-24 April, 2010, Hanoi, Viet Nam.

[11] Ellis, F. and Biggs, S. (2001). Evolving Themes in Rural Development 1950s-2000s. Development Policy Review 19(4), 437-448.

[12] Sultana, P. A., Thompson, P. M., and Ahmed, M. (2001). Women-Led Fisheries Management—A Case Study from Bangladesh. In Global Symposium on Women in Fisheries, Sixth Asian Fisheries Forum, 29 November, Taiwan.

[13] Shelly, A. B. and Costa, M. D. (2001). Women in Aquaculture: Initiatives of CARITAS Bangladesh. In Global Symposium on Women in Fisheries. Sixth Asian Fisheries Forum, 29 November, Taiwan.

[14] Ani, A. O. (2004). Women in Agriculture and Rural Development. Priscaquilla Publishers, Maiduguri, Nigeria.

[15] Ahmed, M., Rab, M. A., and Bimbao, M. A. P. (1999). Household socio-economics resource use and marketing in two thanas of Bangladesh. ICLARM Technical Report, 04, p. 34.

[16] Bhaumik, U., Pandit, P. K., and Chatterjee, J. G. (1993). Involvement of women in the development of inland fisheries. J. Environ, 11(3): 641-644.

[17] WorldFish. (2001). Women in fisheries in Asia. http://pubs.iclarm.net/Pubs/Wif/wifglobal/wifg_asia.pdf. P.48.

[18] Felsing, M., Brugere, C., Kusakabe, K., and Kelkar, G. (2000). Women for aquaculture or aquaculture for women? INFOFISH International, (3), 34-40.

[19] Gopalakrishnan, A. (1996). Role of women in Indian shrimp farming. Naga. Manila. 19(4): 16-18.

[20] Minh, L. T., Huong, D. T., and Tuan, N. A. (1996). Women in Cantho City are profitably involved in fish nursing activities. Aqua. Asia, 1(2), 40-41.

[21] Sultan, S. (1991). Role of women in fisheries. Fish. Chimes, 11(4): 43.

[22] Adeyokunnu, T. O. (1981). Women in Agriculture in Nigeria. ST/ECA/ARCN/81/11: Economic Commission for Africa, Addis Ababa, Ethiopia. 
[23] García, M. M. H. (2013). The role of women in food security. http://Dialnet-TheRoleOfWomenInFoodSecurity-4229912.pdf. P. 96.

[24] Mowla, R. and Kibria, M. G. (2006). An integrated approach on gender issues in coastal fisheries projects in Bangladesh: Problems and challenges. In. Choo PS, Hall SJ, Williams MJ (Editors.), Global Symposium on Gender and Fisheries, pp: 21-28. Seventh Asian Fisheries Forum, 1-2 December 2004, Penang, Malaysia. Penang: World Fish Center.

[25] Baki, M. A. and Bhujel, R. C. (2012). A hands-on training helps proliferation of tilapia culture in Bangladesh. In: Liping L, Fitzsimons K (Editors), Better Science, Better Fish, Better Life. Procedings $9^{\text {th }}$ International Symposium on Tilapia Aquaculture. Aquafish Collaborative Research Support Program, p. 409.

[26] Steel, R. D. G. and Torrie, J. H. (1980). Principles and Procedures of Statistics. McGraw-Hill Book Co., New York, NY, p. 481.

[27] Asaduzzaman, M. (2005). The potentials of organic farming of giant freshwater prawn (Macrobrachium rosenbergii) in Bangladesh. M. S. dissertation, Dept. of Fisheries Management, Bangladesh Agricultural University, Mymensingh.

[28] Ahmed, M., Rab, M. A., and Bimbao, M. P. (2004). Sustainable aquaculture in small water bodies: experience from Bangladesh. In: JA Mathias, AT Charles and H Baotang (Editors), Proceedings of a Workshop on Integrated Fish Farming. Wuxi, China. pp. 392-402.

[29] Wahab, M. A., Ahmed, Z., Islam, M. A., and Rahmatullah, S. M. (1995). Effect of introduction of common carp, Cyprinuscarpio (L) on the pond ecology and growth of fish in polyculture. Aquac. Res. (26), 619-628.

[30] Alabaster. (1982). Water quality criteria for freshwater fish. Second Edition Butterworth’s, London.

[31] Banerjee, S. M. (1967). Water quality and soil condition of fish ponds in some states of India in relation to fish production. Indian Journal of Fisheries, (14): 115-144.

[32] Swingle, H. S. (1969). Standardization of chemical analysis for waters and pond mud. FAO Fish. Res., (4), $397-421$.

[33] Moller, D. (1979). Recent developments in cage and enclosure aquaculture in Norway. In: Advances in aquaculture. Pillay, T. V. R. \& W. A. Dill (editors). Fishing news books, Ltd., Farnham, and Surrey. Pp. 447-453.

[34] Kunda, M., Harun-al-Rashid, A., Morshed, F., Islam, A., and Mazumder, S. K. (2014). Production of Tilapia (Oreochromis niloticus) Fingerling in Hapa Using Swim-Up Fry Involving Women in the Haor Region of Bangladesh. IOSR Journal of Agriculture and Veterinary Science, (7): 2319-2380.

[35] Osofero, S. A., Otubusin, S. O., and Daramola, J. A. (2009). Effect of Stocking Density on Tilapia (Oreochromis niloticus, Linnaeus 1757) Growth and Survival in Bamboo-Net Cages Trial. Afr. J. Biotechnol., (8), 1322-1325. 